\title{
PENGARUH KUALITAS PELAYANAN TERHADAP KEPUASAN NASABAH DI LEMBAGA KEUANGAN MIKRO AGRIBISNIS ( LKMA) SYARIAH AMANAH MANDIRI BAGOR KABUPATEN NGANJUK
}

\author{
Oleh \\ Ahmad Saikhu \\ Institut Agama Islam Pangeran Diponegoro Nganjuk \\ ahmadsaikhu@iaipd-nganjuk.ac.id
}

\begin{abstract}
In the current era of globalization, economic competition is very tight, world development is progressing significantly. Facing the very rapid development of quality human resources and satisfying services is the key to success. Therefore, service quality is an important thing to be assessed about the actual level of service quality for customers in a financial institution. The results showed that the variable service quality has a t-statistic value of 3.366 whose value is greater than the t-table of 2,011 so that the Ho hypothesis is rejected and $\mathrm{Ha}$ is accepted, it can be concluded that the Service Quality variable significantly influences customer decisions. The next result is a significant relationship between Service Quality and Customer Satisfaction of LKMA Bagor based on the results of the analysis using SPSS version 17.
\end{abstract}

Keywords: Effect of Service, Customer Satisfaction, Micro Agribusiness

\begin{abstract}
Abstrak
Dalam era globalisasi saat ini, persaingan ekonomi sangat ketat, perkembangan dunia semakin lama mangalami kemajuan yang signifikan. Menghadapi perkembangan zaman yang sangat pesat SDM yang berkualitas dan pelayanan yang memuaskan menjadi kunci dari keberhasilan.Oleh karena itu Kualitas pelayanan merupakan hal penting untuk dikaji bagaimana sebenarnya tingkat kualitas pelayanan terhadap nasabah pada suatu lembaga Keuangan. Hasil penelitian
\end{abstract}


menunjukan bahwa variabel kualitas pelayanan memiliki nilai tstatistik sebesar 3.366 yang nilainya lebih besar dari t-tabel sebesar 2.011 sehingga hipotesis Ho ditolak dan Ha diterima, dapat disimpulkan bahwa variabel Kualitas Pelayanan berpengaruh signifikan keputusan nasabah. Hasil selanjutnya terdapat hubungan yang signifikan antara Kualitas Pelayanan terhadap Kepuasan Nasabah LKMA Bagor berdasarkan hasil analisa dengan menggunakan SPSS versi 17.

Kata Kunci: Pengaruh Pelayanan, Kepuasan Nasabah, Mikro Agribisnis

\section{Pendahuluan}

Dalam era globalisasi saat ini, perkembangan dunia semakin lama mengalami kemajuan yang sangat signifikan. Menghadapi perubahan dan perkembangan zaman yang sangat pesat, sumber daya manusia yang berkualitas akan menjadi kekuatan bagi perusahaan untuk dapat mempertahankan perusahaannya, terutama dari gempuran pesaing usaha lainnya yang semakin ketat dan tajam. Menghadapi persaingan yang semakin tajam, peran sumber daya manusia yang berkualitas akan sangat membantu pencapaian tujuan perusahaan. Memiliki sumber daya yang berkualitas dapat membantu pemanfaatan kemajuan teknologi dalam menghadapi persaingan usaha, untuk menjaga eksistensi dan kelangsungan hidup perusahaan. ${ }^{21}$ Produk apapun yang dihasilkan tidak terlepas dari unsure pelayanan, baik itu jasa sebagai produk inti, maupun sebagai produk lengkap. Oleh karena itu, dewasa ini perhatian terhadap kepuasan pelanggan semakin besar dan ditingkatkan lagi. Untuk memenangkan persaingan, perusahaan harus mampu memberikan kepuasan kepada para pelanggannya. ${ }^{22}$

Menurut Fandy Tjiptono,kepuasan pelanggan merupakan evaluasi pernbeli di mana alternatif yang dipilih sekurang-kurangnya

\footnotetext{
${ }^{21}$ Kasmir, Bank dan Lembaga Keuangan Lainnya, (Jakarta: PT. Rajagrafindo Persada, 2009) hal. 261.

${ }^{22}$ Hardiyansyah, Kualitas Pelayanan Publik, (Yogyakarta: Gava Medi, 2011) hal. 137.
} 
sama atau melampaui harapan pelanggan, sedangkan ketidakpuasan timbul apabila hasil (outcome) tidak memenuhi harapan. ${ }^{23}$ Menurut penulis apabila pelayanan yang diterima sesuai dengan yang diharapkan, maka kualitas pelayanan dipersepsikan baik dan memuaskan. Jika jasa yang diterima melampaui harapan pelanggan, maka kualitas pelayanan dipersepsikan ideal. Sebaliknya jika pelayanan yang diterima lebih rendah dari pada yang diharapkan, maka kualitas pelayanan dianggap buruk. Hasil pengukuran tingkat kepuasan pelanggan dapat menunjukkan karakteristik atau atribut apa dari produk / jasa yang membuat pelanggan tidakpuas. Tujuan dari pengukuran tingkat kepuasan pelanggan adalah untuk dapat segera mengetahui faktor-faktor yang membuat para pelanggan tidak puas untuk segera diperbaiki, sehingga pelanggan tidak kecewa. Dalam memberikan pelayanan, setidaknya perusahaan harus memenuhi 5 kriteria kualitas pelayanan yang sering disebut RATER sehingga dapat menciptakan pelanggan yang loyal, yaitu reability (kehandalan), assurance (jaminan), tangible (bukti fisik), empathy (komunikasi), dan responsiveness (cepat tanggap). ${ }^{24}$

Peran karyawan sangat penting untuk menunjang keberhasilan setiapperusahaan, terutama perusahaan yang bergerak di sektor jasa. Karena karyawan memiliki kemampuan untuk mempengaruhi persepsi pembeli, karyawan merupakan bagian dari jasa itu sendiri. Sehingga bagi pelanggan, karyawan berfungsi sebagai komunikator sekaligus wakil dari citra perusahaan. Kinerja karyawan ditunjukan melalui kualitas layanan yang diberikan kepada pelanggan sehingga perusahaan dapat mengevaluasi kualitas layanan karyawan.

Salah satu strategi yang dapat menunjang keberhasilan dalam bisnis perbankan adalah berusaha menawarkan kualitas jasa dengan kualitas pelayanan yang nampak dalam kinerja yang tinggi dalam performa dari pelayanan yang ada. Masalah pelayanan sebenarnya bukanlah hal yang sulitatau rumit, tetapi apabila hal ini kurang

${ }^{23}$ Fandy Tjiptono, Pemasaran Jasa (Yogyakarta: Bayumedia 2011), hal. 433.

${ }^{24}$ Suprapto, Pengukuran Tingkat Kepuasan Pelanggan, (Jakarta: Rineka Cipta 2011), hal 45-46. 
diperhatikan maka dapat menimbulkan hal-hal yang rawan karena sifatnya yang sangat sensitif. Sistem pelayanan perlu didukung oleh kualitas pelayanan, fasilitas yang memadai dan etika atau tata krama. Sedangkan tujuan memberikan pelayanan adalah untuk memberikan kepuasan kepada konsumen atau pelanggan sehingga berakibat dengan dihasilkannya nilai tambah atau citra positif bagi perusahaan.

Bank syariah di Indonesia sesungguhnya telah mengalami perkembangan yang cukup pesat. Namun, seiring perkembangan tersebut, perbankan syariah tentunya juga harus didukung oleh sumber daya insani yang memadai, baikdari segi kualitas maupun kuantitasnya. Namun realitas yang ada menunjukan bahwa masih banyak sumber daya insani yang selama ini terlibat di institute syariah tidak memiliki pengalaman akademis maupun praktis dalam perbankan syariah. Sehingga kondisi ini dapat mempengaruhi produktivitas dan berdasarkan penelitian awal penulis saat melakukan observasi di salah satu Lembaga Pembiayaan Syariah, yaitu Lembaga Keuangan Mikro Agribisnis Syariah Amanah Mandiri Bagor dari pernyataan salah satu nasabah yang penulis wawancarai bahwa pelayanan yang diberikan oleh Lembaga Keuangan Mikro Agribisnis Syariah Amanah Mandiri Bagor ini termasuk lambat pada saat proses pengajuan pinjaman yang dilakukan, yang mana hal ini dapat membuat enggannya nasabah untuk datang atau kembali bertransaksi lembaga tersebut. Tetapi walaupun begitu masih banyak nasabah yang melakukan transaksi di Lembaga Keuangan Mikro Agribisnis Syariah Amanah Mandiri Bagor. Oleh karena itu kualitas pelayanan merupakan hal penting yang perlu diperhatikan. Sehingga menarik untuk dikaji bagaimana sebenarnya tingkat kualitas pelayanan terhadap nasabah pada suatu bank.

\section{Metode Penelitian}

Metodologi dalam arti sesungguhnya dapat berarti suatu cara atau jalan. Oleh sebab itu metode dalam hal ini merupakan cara kerja 
yang digunakan untuk memahami dan penyelesaian masalah dari obyek yang menjadi suatu sasaran penelitian. ${ }^{25}$

Penelitian ini adalah dilakukan untuk mengetahui ada tidaknya hubungan antara variabel-variabel yang diteliti. Kemudian dianalisa dengan menggunakan uji hipotesa antara variabel bebas dengan variabel terikat. Dalam upaya untuk memperoleh data berakhir dengan hasil yang valid, maka harus dipergunakan metode penelitian yang sesuai dengan obyek yang digunakan sebagai tempat penelitian. Penelitian juga dilakukan penelitian Survei, yaitu penelitian yang mengambil sampel dari satu populasi dan menggunakan kuesioner sebagai alat pengumpulan data yang pokok. Pada umumnya merupakan unit analisis dalam penelitian survei adalah individu (Singarimbun dan Effendi, 1995).

Penelitian survei ini menggunakan tipe penelitian penjelasan yakni memberikan penjelasan antara variabel-variabel melalui pengujian hipotesa. Dalam hal ini menjelaskan hubungan antara kualitas kerja dan pelayanan karyawan dengan kepuasan pelanggan. Sedangkan pendekatan penelitian yang digunakan adalah pendekatan kuantitatif, yaitu suatu pendekatan penelitian yang menggunakan cara pendiskripsikan suatu masalah yang ada dan menggunakan teori yang telah ada dan menggunakan pendekatan kualitatif yaitu dengan menggunakan angka. ${ }^{26}$

1. Populasi dan Sampel Penelitian

Data yang digunakan dalam penelitian ini adalah data primer. Data primer adalah data yang diperoleh peneliti dari lapangan melalui observasi. Artinya, data yang diperoleh dari subjek penelitian dengan menggunakan system angket yang kemudian diolah untuk menjadi

${ }^{25}$ Bambang, Prasetyo dan Lina Miftahul Jannah, Metode Penenlitian Kuantitatif, (Jakarta: PT Raja Grafindo Persada, 2005), hal.67.

${ }^{26}$ Burhan Bungin, Metodologi Penuelitian Sosial Format-Format Kuantitatif dan Kualitatif, (Surabaya: Airlangga University Press, 2001) hal. 129. 
bahan penelitian. ${ }^{27}$ Adapun metode yang digunakan dalam penelitian ini adalah sebagai berikut:

a. Populasi yaitu seluruh kumpulan elemen yang menunjukkan ciriciri tertentu yang dapat dipergunakan untuk membuat kesimpulan.Populasi dari peneliti ini adalah seluruh nasabah yang berjumlah 100 nasabah.

b. Sampel yaitu bagian dari elemen-elemen populasi yang terpilih. ${ }^{28}$ Penulis menentukan sampel sebagian nasabah LKMA SyariahAmanahMandiri.Teknik pengambilan sampel adalah cara bagaimana peneliti mengambil sampel dalam penelitian dari populasi yang tersedia. Dalam penelitian ini penulis menggunakan teknik pengambilan sampel dengan cara mengambil sampel secara acak sederhana yaitu proses memilih satuan sampling dalam populasi mempunyai peluang yang sama untuk terpilih ke dalam sampel. Sedangkan teknik pengambilan sampel menggunakan rumus dari Taro Yamane atau Slovin adalah sebagai berikut :

$$
\begin{aligned}
& \mathrm{n}=\frac{\mathrm{N}}{\mathrm{N} \cdot \mathrm{d}^{2}+1} \\
& \mathrm{n}=\text { jumlah sample } \\
& \mathrm{N}=\text { (jumlah populasi }=100 \text { responden) } \\
& \mathrm{d}^{2}=\text { presisi (ditetapkan } 10 \% \text { dengan tingkat kepercayaan }
\end{aligned}
$$

Berdasarkan rumus tersebut di peroleh jumlah sampel sebagai berikut:

$$
n=\frac{N}{N \cdot d^{2}+1}=\frac{100}{100.01^{2}+1}=\frac{100}{2}=50
$$

jadi jumlah sampel dalam penelitian ini, penulis mengambil 50 orang sampel yang dianggap dapat mewakili.

\section{Teknik Pengambilan Data}

${ }^{27}$ urhan Bungin, Metodologi Penelitian Kuantitatif, (Jakarta:

Prenada Media, 2005), hal. 129-152.

${ }^{28}$ Suharsimi Arikunto, Prosedur Penelitian Suatu Pendekatan Praktis, (Jakarta: Rineka

Cipta, 1991) hal. 102. 
1. Wawancara (interview) merupakan cara yang dapat digunakan peneliti untuk mengumpulkan data tanpa melakukan test dalam melalui wawancara. Sesuai tidaknya data yang diinginkan oleh sebuah penelitian sangat dipengaruhi oleh beberapa aspek wawancara, bahan wawancara (dituangkan dalam daftar pertanyaan dan situasi wawancara). Karena pada hakikatnya wawancara merupakan kegiatan perolehan informasi, maka kemahiran peneliti dalam wawancara untuk menggali informasi menjadi penting.32 Dengan itu peneliti melakukan wawancara dengan teliti dan seksama dengan pertanyaan-pertanyaan yang sesuai dengan judul penelitian.

2. Kuesioner adalah seperangkat pertanyaan atau pernyataan yang harus dijawab atau dilengkapi oleh responden. Secara umum kuesioner dapat memuat pertanyaan tentang fakta, pertanyaan tentang pendapat (opini) atau sikap. ${ }^{29}$ Bentukbentuk skala sikap yang biasa dipakai diantaranya model skala Likert yaitu: model skala Likert adalah bentuk kuesioner yang mengungkap sikap dari responden dalam bentuk jawaban (pernyataan) yang berupa Sangat Setuju (SS), Setuju (S), Tidak ada Pendapat (N), Tidak Setuju (TS) dan Sangat Tidak Setuju (STS). Setiap jawaban tersebut memiliki skor sendiri sesuai dengan positif atau negatifnya item itu.

\section{Tabel 3.1}

Pedoman Skala Likert

$\begin{array}{ccc}\text { No } & \text { Keterangan } & \text { Skor } \\ 1 & \text { Sangat Setuju (SS) } & 5 \\ 2 & \text { Setuju (S) } & 4 \\ 3 & \text { Tidak ada Pendapat (N) } & 3 \\ 4 & \text { Tidak Setuju (TS) } & 2 \\ 5 & \text { Sangat Tidak Setuju (STS) } & 1\end{array}$

${ }^{29}$ Suharsimi Arikunto, Prosedur Penelitian Suatu Pendekatan Praktis, (Jakarta: Rineka Cipta, 1991) hal. 102. 


\section{Landasan Teori}

\section{A. Penelitian Terdahulu}

Penelitian-penelitian terdahulu merupakan acuan bagi peneliti terutama dalam pemetaan permasalahan yang menjadi latar belakang permasalahan dalam topik menjadi latar belakang permasalahan dalam topic penelitian kepuasan nasabah. Pada umumnya penelitian tentang Kualitas pelayanan terhadap kepuasan nasabah mengangkat permasalahan persaingan dan peningkatan pangsa pasar serta pengembangan produk untuk dapat merekomendasikan strategi pemasaran berdasarkan perilaku konsumen. Analisis yang digunakan dalam penelitian ini sama dengan yang digunakan oleh penelitian terdahulu diatas, yaitu analisis Structural Equation Modeling (SEM) untuk melihat variabel-variabel yang menjadi prioritas utama yang penting menurut konsumen dan untuk mengetahui tingkat kepuasan konsumen secara menyeluruh terhadap mutu pelayanan.

Pada kajian penelitian terdahulu, peneliti mengambil beberapa penelitian yang terkait dengan topic penelitian yaitu kualitas pelayanan dan kepuasan nasabah. Hal tersebut bertujuan untuk melihat perbandingan antara penelitian terdahulu dengan penelitian ini sehingga dapat menunjukkan adanya persamaan dan perbedaan pada penelitian. Muhammad Guntur SW Skripsi pada Fakultas Syariah IAIN Semarang dengan penelitiannya Kualitas Pelayanan (Service Quality) Terhadap Kepuasan Pelanggan pada PDAM kota Surakarta menunjukkan bahwa Variabel X dan Y berpengaruh signifikan. Begitu juga dengan peneliti asal Fakultas Ekonomi Universita Gunadarma, Hartono dengan judul skripsi Analisis Kualitas Pelayanan terhadap Kepuasan Nasabah PT. Bank JATENG Cabang Purworejo menunjukkan Variabel $\mathrm{X}$ dan $\mathrm{Y}$ berpengaruh signifikan. Namun berbeda dengan Endang Purwanti, mahasiswa asal Fakultas Ekonomi STKIP Jakarta dengan judul skripsi Pengaruh Kualitas Pelayanan Terhadap Kepuasan Pelanggan pada Loket KCA (Kredit Cepat Aman) Cabang Perum Pegadaian Pasar Rumput menghasilkan Variabel X dan $\mathrm{Y}$ berpengaruh namun tidak signifikan. 


\section{B. Teori Kualitas Pelayanan}

Kualitas merupakan salah satu kunci dalam memenangkan persaingan dengan pasar.Ketika perusahaan telah mampu menyediakan produk berkualitas maka telah membangun salah satu pondasi untuk menciptakan kepuasan pelanggan. Menurut Goetsch dan Davis (1994) yang dikutip oleh Tjiptono (2012:152), kualitas dapat diartikan sebagai "kondisi dinamis yang berhubungan dengan produk, jasa, sumber daya manusia, proses, dan lingkungan yang memenuhi atau melebihi harapan". Berdasarkan definisi ini, kualitas adalah hubungan antara produk dan pelayanan atau jasa yang diberikan kepada konsumen dapat memenuhi harapan dan kepuasan konsumen. ${ }^{30}$

Kualitas adalah kesesuaian dengan kebutuhan pasar atau konsumen.(Abubakar \& Siregar, 2010 : p.2.Tjiptono dan Sunyoto (2012) mengatakan bahwa kualitas merupakan: "sebuah kondisi dinamis yang berhubungan dengan produk, jasa, manusia, proses, dan lingkungan yang memenuhi atau melebihi harapan." Sunyoto (2012) menyatakan bahwa kualitas merupakan suatu ukuran untuk menilai bahwa suatu barang atau jasa telah mempunyai nilai guna seperti yang dikehendaki atau dengan kata lain suatu barang atau jasa dianggap telah memiliki kualitas apabila berfungsi atau mempunyai nilai guna seperti yang diinginkan.

Dari beberapa definisi tersebut dapat disimpulkan bahwa kualitas adalah unsure yang saling berhubungan mengenai mutu yang dapat mempengaruhi kinerja dalam memenuhi harapan pelanggan.Kualitas tidak hanya menekankan pada hasil akhir, yaitu produk dan jasa tetapi menyangkut kualitas manusia, kualitas proses, dan kualitas lingkungan. ${ }^{31}$ Dalam menghasilkan suatu produk dan jasa yang berkualitas melalui manusia dan proses yang berkualitas. Menurut Garvin (1984) yang dikutip oleh Tjiptono (2012:143), setidaknya ada lima perspektif kualitas yang berkembang saat ini:

\footnotetext{
${ }^{30}$ M.N. Nasution, Manajemen Jasa Terpadu, (Bogor: Ghalia Indonesia, 2004) h. 41.

${ }^{31}$ M.N. Nasution, Manajemen Jasa Terpadu, (Bogor: Ghalia Indonesia, 2004) h. 43.
} 
1. Transcendental Approach. Dalam persoektif ini, kualitas dipandang sebagai innate excellence, yaitu sesuatu yang secara intuitif dapat dipahami, namun nyaris tidak mungkin dikomunikasikan, sebagai conoh kecantikan atau cinta. Perpektif ini menegaskan bahwa orang hanya bisa belajar memahami kualitas melalui pengalaman yang didapatkan dan eksposure berulang kali (repeated exposure).

2. Product-Based Approach. Perspektif ini mengasumsikan bahwa kualitas merupakan karakteristik,komponen atau atribut objektif yang dapat dikuantitatifkan dan dapat diukur.Perbedaan dalam hal kualitas mencerminkan perbedaan dalam jumlah beberapa unsur atau atribut yang dimiliki produk.Semakin banyak atribut yang dimiliki sebuah produk atau merek, semakin berkualitas produk atau merek bersangkutan.

3. User-Based Approach. Perspektif ini didasarkan pada pemikiran bahwa kualitas tergantung pada orang yang menilainya (eyes of the beholder), sehingga produk yang paling memuaskan preferensi seseorang (maximum satisfaction) merupakan produk yang berkualitas paling tinggi. Perspektif yang bersifat subyektif dan demandoriented ini juga menyatakan bahwa setiap pelanggan memiliki kebutuhan dan keinginan masing-masing yang berbeda satu sama lain, sehingga kualitas bagi seseorang adalah sama dengan kepuasan maksimum yang dirasakan. ${ }^{32}$

4. Based Approach. Perspektif ini bersifat supply-based dan lebih berfokus pada praktik-praktik dan pemanufakturan, serta mendefinisikan kualitas sebagai kesesuaian atau kecocokan dengan persyaratan (conformance to requirements).Dalam konteks bisnis jasa, kualitas berdasarkan perspektif ini cenderung bersifat operation-driven.

5. Value-Based Approach. Perspektif ini memandang kualitas dari aspek nilai (value) dan harga (price).Dengan mempertimbangkan trade-off antara kinerja dan harga, kualitas didefinisikan sebagai affordable excellence, yakni tingkat kinerja 'terbaik' atau sepadan

${ }^{32}$ Tjiptono, Pemasaran Jasa (Yogyakarta: Bayumedia 2012), hal. 14. 
dengan harga yang dibayarkan. Kualitas dalam perspektif ini bersifat relatif, sehingga produk yang memiliki kualitas paling bernilai adalah barang atau jasa yang paling tepat dibeli (bestbuy).

\section{Definisi Pelayanan}

Aktivitas, manfaat maupun kepuasan merupakan bentuk pelayanan yang pada dasarnya tidak berwujud. Hal ini diungkapkan Gronroos yang dikutip oleh Tjiptono (2011:17) menyatakan bahwa pelayanan merupakan proses yang terdiri atas serangkaian aktivitas intangible (tidak berwujud) yang biasanya (namun tidak harus selalu) terjadi pada interaksi antara konsumen dengan karyawan jasa, sumber daya fisik, barang, atau sistem penyedia jasa yang disediakan sebagai solusi atas masalah konsumen. Dari definisi ini, dapat dikatakan bahwa pelayanan merupakan aktivitas yang diberikan kepada konsumen dan pada dasarnya tidak berwujud disediakan sebagai solusi atau masalah konsumen. ${ }^{33}$

Kotler (2013:37) mengemukakan bahwa jasa atau layanan memiliki empat karakteristik utama yaitu:

1. Intangibility (tidak berwujud). Jasa atau layanan berbeda secara signifikan dengan barang fisik. Bila barang merupakan suatu objek, benda, material yang bisa dilihat, disentuh dan dirasa dengan panca indra, maka jasa atau layanan justru merupakan suatu perbuatan, tindakan, pengalaman, proses, kinerja (performance) atau usaha yang sifatnya abstrak. Bila barang dapat dimiliki, maka jasa/layanan cenderung hanya dapatdikonsumsi tetapi tidak dapat dimiliki (non ownership).Jasa juga bersifat intangible, artinya jasa tidak dapat dilihat, dirasa, dicium, didengar atau diraba sebelum dibeli dan dikonsumsi. Seorang

${ }^{33}$ Fandy Tjiptono,Mengukur Kinerja Pelayanan dan Kepuasan Konsumen (Edisi Revisi), (Bandung: Pustaka Reka Cipta 2015), h. 71. 
konsumen jasa tidak dapat menilai hasil dari sebuah jasa sebelum ia mengalami atau mengkonsumsinya sendiri. ${ }^{34}$

2. Inseparability (tidak terpisahkan). Barang biasanya diproduksi terlebih dahulu, kemudian dijual, baru dikonsumsi. Sedangkan jasa umumnya dijual terlebih dahulu, baru kemudian diproduksi dan dikonsumsi pada waktu dan tempat yang sama. Interaksi antara penyedia jasa dan pelanggan merupakan ciri khusus dalam pemasaran jasa layanan bersangkutan.Keduanya mempengaruhi hasil (outcome) dari jasa/layanan bersangkutan.Hubungan antara penyedia jasa dan pelanggan ini, efektivitas staff layanan merupakan unsur kritis. Implikasinya, sukses tidaknya jasa atau layanan bersangkutan ditunjang oleh kemampuan organisasi dalam melakukan proses rekrutmen dan seleksi, penilaian kinerja, systemkompensansi, pelatihan, dan pengembangan karyawan secara efektif.

3. Variability. Layanan sangat bervariasi Kualitas tergantung pada siapa yang menyediakan mereka dan kapan dan dimana kualitas layanan disediakan. Ada beberapa penyebab variabilitas layanan dimana jasa diproduksi dan dikonsumsi secara bersama-sama sehingga membatasi control kualitas. Permintaan yang tidak tetap membuat sulit untuk memberikan produk yang konsisten dan tetap selama permintaan tersebut berada dipuncak. Tingginya tingkat kontak antarapenyedia layanan dan tamu, berarti bahwakonsistensi produk tergantung padakemampuan penyedia layanan dan kinerja pada saat yang sama. Seorang tamu dapat menerima pelayanan yang sangat baik selama satu hari dan mendapat pelayanan dari orang yang sama keesokan harinya. ${ }^{35}$

4. Perishability (tidak tahan lama). Perishability berarti bahwa jasa atau layanan adalah komoditas yang tidak tahan lama, tidak dapat disimpan untuk pemakaian ulang di waktu yang akandatang, dijual kembali, atau dikembalikan.Permintaan jasa juga bersifat

\footnotetext{
${ }^{34}$ Kotler Philip,Manajemen Pemasaran jilid 2, Erlangga, Jakarta,
} 2013, hal. 64 .

${ }^{35}$ Kotler Philip,Manajemen Pemasaran jilid 2, Erlangga, Jakarta, 2013, hal. 64. 
fluktuasi dan berubah, dampaknya perusahaan jasa seringkali mengalami masalah sulit.Oleh karena itu perusahaan jasa merancang strategi agar lebih baik dalam menjalankan usahanya dengan menyesuaikan permintaan dan penawaran.

\section{Definisi dan Dimensi Pokok Kualitas Pelayanan}

Menurut Lewis dan Booms (1983) yang dikutip oleh Tjiptono (2011:180) kualitas jasa sebagai ukuran seberapa bagus tingkat layanan yang diberikan mampu sesuai dengan ekspetasi konsumen. Berdasarkan definisi ini, kualitas layanan ditentukan oleh kemampuan perusahaan memenuhi kebutuhan dan keinginanKonsumen sesuai dengan ekspetasi konsumen.Tjiptono dalam Sunyoto (2012) mengatakan bahwa kualitas atau mutu dalamindustri jasa pelayanan adalah suatu penyajian produk atau jasa sesuai ukuran yang berlaku di tempat produk tersebut diadakan dan penyampaiannya setidaknya samadengan yang diingkan dan diharapkan oleh konsumen. ${ }^{36}$

Menurut Sunyoto (2012), "Mutu pelayanan berpusat pada upaya pemenuhan kebutuhan dan keinginan konsumen serta ketepatan penyampaiannya untuk mengimbangi harapan konsumen, yaitu adanya kesesuaian antara harapan dengan persepsi manajemen, adanya kesesuaian antara persepsi atas harapan konsumen dengan standar kerja karyawan, adanya kesesuaian antara standar kerja karyawan dengan pelayanan yang diberikan dengan pelayanan yang dijanjikan adanya kesesuaian antara pelayanan yang diterima dengan yang diharapkan dengan konsumen" ${ }^{37}$ Beberapa definisi diatas penulis menyimpulkan bahwa kualitas pelayanan merupakan suatu penyajian produk atau jasa yang sesuai dengan standar perusahaan dan diupayakan dalam penyampaian produk dan jasa tersebut samadengan apa yang diharapkan tamu restoran atau melebihi ekspetasi tamu.

\footnotetext{
${ }^{36}$ Sunyoto, Danang, Konsep Dasar Riset Pemasaran dan Perilaku Konsumen, Erlangga, Jakarta, 2013, hal. 23.

${ }^{37}$ Sunyoto, Danang, Konsep Dasar Riset Pemasaran dan Perilaku Konsumen, Erlangga, Jakarta, 2013, hal. 25.
} 
Menurut Parasuraman yang dikutip oleh Tjiptono (2011:198) terdapat lima dimensi pokok dalam kualitas pelayanan sebagai berikut:

1. Reliabilitas (reliability). Berkaitan dengan kemampuan perusahaan untuk memberikan pelayanan yang akurat sejak pertama kali tanpa melakukan kesalahan apapun dan menyampaikan jasanya sesuai dengan waktu yang disepakati.

2. Daya Tanggap (Responsiveness). Berhubungan dengan kesediaan dan kemampuan karyawan untuk membantu para konsumen dan merespon permintaan mereka, serta menginformasikan kapan jasa akan diberikan dan kemudian memberikan jasa secara cepat.

3. Jaminan (Assurance). Perilaku karyawan yang mampu menumbuhkan kepercayaan konsumen terhadap perusahaan dan perusahaan bisa menciptakan rasa aman bagi para konsumennya.Jaminan juga berarti bahwa para karyawan selalu bersikap sopan dan menguasai pengetahuan dan keterampilan yang dibutuhkan untuk menangani setiap pertanyaan atau masalah konsumen.

4. Empati (Empathy). Menyatakan bahwa perusahaan memahami masalah para konsumennya dan bertindak demi kepentingan konsumen, serta memberikan perhatian personal kepada para konsumen dan memiliki jam operasi yang nyaman.

5. Bukti Fisik (Tangible). Berkenaan dengan daya tarik fasilitas fisik, peralatan/perlengkapan yanglengkap, dan material yang digunakan perusahaan bersih, serta penampilan dari karyawan rapi.

Berdasarkan kelima dimensi kualitas layanan tersebut, maka kepuasan pelanggan dapat diukur, dipahami dan dijadikan sebagai suatu hasil yang baik untuk kepentingan peningkatan kualitas pelayanan jasa yang diberikan kepada pelanggan, baik pelanggan yang baru pertama kali maupun pelanggan yang sudah berulang-ulang menggunakan jasa tersebut. ${ }^{38}$

${ }^{38}$ Tjiptono, Fandy, Service Management Mewujudkan Layanan

Prima, Erlangga, Jakarta, 2012, hal. 201. 


\section{E. Komplain Nasabah}

Pelanggan akan mengeluh atau komplain apabila merasa tidak puas. Complain atau keluhan adalah pengaduan atau penyampaian ketidakpuasan, ketidaknyamanan, kejengkelan, dan kemarahan atas service jasa atau produk. ${ }^{39}$

1. Komplain Pelanggan

a. Berkaitan dengan produk atau jasa dan layanan

b. Penting diatasi

c. Komplain yang tidak ditanggapi secara memuaskan bias menyebabkan hubungan negative atau konflik.pelanggan. Pelanggan akan mengeluh apabila tidak mendapatkan pelayanan atau produk yang tidak sesuai dengan biaya yang dikeluarkan.

2. Bentuk dan Jenis Komplain

a. Keluhan yang bersumbe pada masalah teknik

b. Komplain karena sikap negative petugas pelayanan (melayani dengan sikap curiga, sinis, tidak ramah, kasar, dan sebagainya)

c. Komplain karena pelayanan yang kurang memuaskan (lama, berbelit, pungli, tidak sesuai dengan spesifikasi yang diminta konsymen, dan sebagainya)

d. Komplain yang tidak biasa atau aneh, dibuat-buat, dimunculkan konsumen untuk menarik perhatian

e. Konsumen yang secara psikilogis kurang bahagia, hanya ingin didengar saja

3. Cara Penyampaian Komplain

a. Voice Response (Langsung)

Voice Response adalah Penyampaian complain secara langung, menyampaikan pada petugas, staf yang ditemui.

b. Private Response (Tidak langsung)

${ }^{39}$ Bahrul Kirom, Mengukur Kinerja Pelayanan dan Kepuasan Konsumen (Edisi Revisi), (Bandung: Pustaka Reka Cipta 2015), h. 34 
Privat Response adalah penyampaian komplai tidak secara langsung, melalui pihak ketiga (media masa, surat pembaca, LSM, dll)

c. Tbird Party Response (Jalur Hukum)

Komplain melalui jalur hukum atau class action pada pelanggan tidak akan ditanggapi apabila konsumen resah atau timbul ketidakpuasan, menurunkan profesionalisme perusahaan, menurunkan image perusahaan, perusahaan ditinggalkan konsumen. Jika komplain ditangani dengan baik maka pelanggan akan meningjatkan kepercayaan konsumen, meningkatkan hubungan positif dengan konsumen.

Aspek penting yang harus dikedepankan dalam menangani keluhan pelanggan ;

1. Rasa empati kepada pelanggan, perusahaan banyak meluangkan waktu agar keluhan pelanggan tersalurkan

2. Kecepatan tanggapan, dengan cara memberikan tanggapan secepat mungkin akan merupakan solusi terbaik yang diinginkan konsumen

3. Kemudahan menghubungi perusahaan,seperti jalur komunikasi bebas pula.

Perusahaan akan mengatasi pelanggan apabila pelanggan mengalami keluhan yaitu dengan cara mendengarkan apa yang dibicarakan pelanggan dengan baik, meminta maaf dengan tulus dan tanyakan pada mereka bagaimana anda bias memperbaikinya.Perusahaan yang efektif dalam menyelesaikan kelihan pelanggan akan melakukan pengembangan progam pelatiha danmengembangkan pedoman perbaikan pelayanan untuk mencapai kepuasan pelanggan. ${ }^{40}$

${ }^{40}$ Arief Muhtosim, Pemasaran Jasa dan Kualitas Pelayanan, Bayumedia, Jakarta, 2007, hal. 56. 


\section{Hasil Penelitian}

1. Karakteristik Responden

Berdasarkan data hasil penelitian, terdapat beberapa karakteristik responden yang mengisi kuisoner. Berikut adalah tabelnya:

Tabel 4.1

Responden Berdasarkan Jenis Kelamin

\begin{tabular}{|c|c|}
\hline Pria & $24 \%$ \\
\hline Wanita & $76 \%$ \\
\hline
\end{tabular}

Sumber: Hasil Pengolahan Microsoft Word 2007

Jenis kelamin responden dalam penelitian ini adalah $24 \%$ lakilaki dengan jumlah 12 orang dan $76 \%$ perempuan dengan jumlah 38 orang.

Tabel 4.2

Responden Berdasarkan usia

\begin{tabular}{|c|c|}
\hline Usia $20-30$ & $16 \%$ \\
\hline Usia $30-40$ & $38 \%$ \\
\hline Usia $40-50$ & $42 \%$ \\
\hline Usia $>50$ & $4 \%$ \\
\hline
\end{tabular}

Sumber: Hasil Pengolahan Microsoft Word 2007

Usia responden dalam penelitian ini adalah $4 \%$ atau sebanyak 2 responden berusia 20-30 tahun, $42 \%$ atau sebanyak 21 responden berusia 30-40 tahun, $38 \%$ atau sebanyak 19 responden berusia 40-50 tahun, dan $18 \%$ atau sebanyak 8 responden berusia $>50$ tahun.

Tabel 4.3

Responden Berdasarkan profesi

\begin{tabular}{|c|c|}
\hline Pegawai Negeri & $4 \%$ \\
\hline Pengusaha / Pedagang & $52 \%$ \\
\hline Wiraswasta & $44 \%$ \\
\hline
\end{tabular}

Sumber: Hasil Pengolahan Microsoft Word 2007

Sebanyak $4 \%$ atau 2 responden berprofesi sebagai pegawai negeri, $52 \%$ atau 26 responden berprofesi sebagai 
pengusaha/pedagang, dan $44 \%$ atau 22 responden berprofesi sebagai pegawai swasta.

Tabel 4.4

Responden Berdasarkan Pendidikan Terakhir

\begin{tabular}{|c|c|}
\hline SD & $10 \%$ \\
\hline SLTP & $50 \%$ \\
\hline SLTA & $32 \%$ \\
\hline S1 & $8 \%$ \\
\hline
\end{tabular}

Sumber: Hasil Pengolahan Microsoft Word 2007

Pendidikan terakhir responden dalam penelitian ini adalah lulusan SD sebanyak $10 \%$ atau 5 responden, lulusan SLTP sebanyak $50 \%$ atau 25 responden, lulusan SLTA sebanyak $32 \%$ atau 16 responden, dan lulusan S1 keatas sebanyak $8 \%$ atau 4 responden.

2. Hasil Kuisoner

Berikut adalah hasil kuisoner yang disebarkan kepada nasabah pegadaian LKMA Syariah Amanah Mandiri Bagor (responden):

Tabel 4.5

Hasil Kuisoner

a. Variabel Kualitas Pelayanan (X)

$\begin{array}{cccccccccccc}\text { NO } & \mathbf{1} & \mathbf{2} & \mathbf{3} & \mathbf{4} & \mathbf{5} & \mathbf{6} & \mathbf{7} & \mathbf{8} & \mathbf{9} & \mathbf{1 0} & \text { TOTAL } \\ \mathbf{1} & 4 & 4 & 5 & 4 & 4 & 4 & 5 & 5 & 4 & 5 & 44 \\ \mathbf{2} & 5 & 5 & 5 & 4 & 5 & 5 & 5 & 5 & 4 & 5 & 48 \\ \mathbf{3} & 4 & 4 & 4 & 3 & 4 & 4 & 4 & 5 & 3 & 4 & 39 \\ \mathbf{4} & 4 & 4 & 4 & 4 & 4 & 4 & 5 & 4 & 4 & 5 & 42 \\ \mathbf{5} & 4 & 4 & 5 & 5 & 4 & 4 & 5 & 5 & 5 & 5 & 46 \\ \mathbf{6} & 5 & 4 & 4 & 3 & 5 & 4 & 4 & 4 & 3 & 5 & 41 \\ \mathbf{7} & 4 & 5 & 5 & 5 & 4 & 5 & 4 & 4 & 5 & 4 & 45 \\ \mathbf{8} & 5 & 5 & 5 & 4 & 5 & 5 & 4 & 4 & 4 & 4 & 45 \\ \mathbf{9} & 5 & 5 & 5 & 5 & 5 & 5 & 5 & 5 & 5 & 5 & 50 \\ \mathbf{1 0} & 4 & 4 & 5 & 4 & 4 & 4 & 5 & 5 & 4 & 5 & 44 \\ \mathbf{1 1} & 4 & 4 & 5 & 5 & 4 & 4 & 5 & 4 & 5 & 5 & 45 \\ \mathbf{1 2} & 5 & 4 & 5 & 3 & 5 & 4 & 5 & 5 & 3 & 5 & 44 \\ \mathbf{1 3} & 4 & 3 & 4 & 4 & 4 & 3 & 5 & 4 & 4 & 4 & 39 \\ \mathbf{1 4} & 4 & 4 & 4 & 4 & 4 & 4 & 5 & 4 & 4 & 4 & 41 \\ \mathbf{1 5} & 5 & 5 & 4 & 3 & 5 & 5 & 4 & 4 & 3 & 5 & 43\end{array}$


$\begin{array}{llllllllllll}16 & 3 & 4 & 5 & 3 & 3 & 4 & 5 & 3 & 3 & 5 & 38\end{array}$

$\begin{array}{llllllllllll}17 & 5 & 5 & 5 & 5 & 5 & 5 & 5 & 5 & 5 & 5 & 50\end{array}$

$\begin{array}{llllllllllll}18 & 4 & 4 & 5 & 4 & 4 & 4 & 4 & 4 & 4 & 5 & 42\end{array}$

$\begin{array}{llllllllllll}19 & 3 & 4 & 5 & 3 & 3 & 4 & 3 & 5 & 3 & 5 & 38\end{array}$

$\begin{array}{llllllllllll}20 & 5 & 4 & 4 & 5 & 5 & 4 & 5 & 5 & 5 & 5 & 47\end{array}$

$\begin{array}{llllllllllll}21 & 5 & 4 & 5 & 3 & 5 & 4 & 4 & 4 & 3 & 5 & 42\end{array}$

$\begin{array}{llllllllllll}22 & 4 & 4 & 4 & 3 & 4 & 4 & 4 & 4 & 3 & 4 & 38\end{array}$

$\begin{array}{llllllllllll}23 & 5 & 4 & 5 & 4 & 5 & 4 & 5 & 4 & 4 & 4 & 44\end{array}$

$\begin{array}{llllllllllll}24 & 5 & 4 & 4 & 5 & 5 & 4 & 5 & 5 & 5 & 4 & 46\end{array}$

$\begin{array}{llllllllllll}25 & 4 & 4 & 5 & 4 & 4 & 4 & 5 & 4 & 4 & 5 & 43\end{array}$

$\begin{array}{llllllllllll}26 & 3 & 3 & 4 & 5 & 3 & 3 & 5 & 4 & 5 & 4 & 39\end{array}$

$\begin{array}{llllllllllll}27 & 5 & 4 & 4 & 4 & 5 & 4 & 4 & 4 & 4 & 4 & 42\end{array}$

$\begin{array}{llllllllllll}28 & 5 & 4 & 4 & 5 & 5 & 4 & 5 & 5 & 5 & 4 & 46\end{array}$

$\begin{array}{llllllllllll}29 & 5 & 5 & 4 & 4 & 5 & 5 & 5 & 4 & 4 & 5 & 46\end{array}$

$\begin{array}{llllllllllll}30 & 5 & 4 & 5 & 3 & 5 & 4 & 5 & 4 & 3 & 4 & 42\end{array}$

$\begin{array}{llllllllllll}31 & 4 & 5 & 5 & 3 & 4 & 5 & 5 & 4 & 3 & 5 & 43\end{array}$

$\begin{array}{llllllllllll}32 & 5 & 4 & 5 & 3 & 5 & 4 & 5 & 4 & 3 & 4 & 42\end{array}$

$\begin{array}{llllllllllll}33 & 5 & 4 & 5 & 4 & 5 & 4 & 5 & 3 & 4 & 5 & 44\end{array}$

$\begin{array}{llllllllllll}34 & 4 & 4 & 4 & 4 & 4 & 4 & 5 & 4 & 4 & 3 & 40\end{array}$

$\begin{array}{llllllllllll}35 & 4 & 3 & 4 & 4 & 4 & 3 & 4 & 4 & 4 & 4 & 38\end{array}$

$\begin{array}{llllllllllll}36 & 4 & 4 & 4 & 4 & 4 & 4 & 5 & 4 & 4 & 4 & 41\end{array}$

$\begin{array}{llllllllllll}37 & 4 & 4 & 4 & 4 & 4 & 4 & 4 & 4 & 4 & 4 & 40\end{array}$

$\begin{array}{llllllllllll}38 & 5 & 3 & 4 & 5 & 5 & 3 & 4 & 3 & 5 & 5 & 42\end{array}$

$\begin{array}{llllllllllll}39 & 5 & 4 & 5 & 5 & 5 & 4 & 5 & 5 & 5 & 5 & 48\end{array}$

$\begin{array}{llllllllllll}40 & 5 & 4 & 4 & 4 & 5 & 4 & 4 & 4 & 4 & 4 & 42\end{array}$

$\begin{array}{llllllllllll}41 & 5 & 4 & 5 & 4 & 5 & 4 & 5 & 5 & 4 & 4 & 45\end{array}$

$\begin{array}{llllllllllll}42 & 4 & 5 & 5 & 4 & 4 & 5 & 5 & 5 & 4 & 5 & 46\end{array}$

$\begin{array}{llllllllllll}43 & 5 & 4 & 5 & 4 & 5 & 4 & 5 & 4 & 4 & 4 & 44\end{array}$

$\begin{array}{llllllllllll}44 & 4 & 4 & 5 & 3 & 4 & 4 & 5 & 4 & 3 & 5 & 41\end{array}$

$\begin{array}{llllllllllll}45 & 5 & 4 & 5 & 4 & 5 & 4 & 5 & 4 & 4 & 5 & 45\end{array}$

$\begin{array}{llllllllllll}46 & 5 & 4 & 4 & 4 & 5 & 4 & 5 & 5 & 4 & 5 & 45\end{array}$

$\begin{array}{llllllllllll}47 & 5 & 4 & 5 & 5 & 5 & 4 & 5 & 4 & 5 & 5 & 47\end{array}$

$\begin{array}{llllllllllll}48 & 5 & 4 & 5 & 4 & 5 & 4 & 5 & 4 & 4 & 5 & 45\end{array}$

$\begin{array}{llllllllllll}49 & 5 & 4 & 5 & 4 & 5 & 4 & 5 & 5 & 4 & 5 & 46\end{array}$

$\begin{array}{llllllllllll}\mathbf{5 0} & 4 & 4 & 4 & 4 & 4 & 4 & 5 & 5 & 4 & 5 & 43\end{array}$ 
b. Variabel Kepuasan Nasabah (Y)

$\begin{array}{cccccccccccc}\text { NO } & \mathbf{1} & \mathbf{2} & \mathbf{3} & \mathbf{4} & \mathbf{5} & \mathbf{6} & \mathbf{7} & \mathbf{8} & \mathbf{9} & \mathbf{1 0} & \text { TOTAL } \\ \mathbf{1} & 5 & 4 & 5 & 5 & 5 & 4 & 4 & 5 & 4 & 5 & 46 \\ \mathbf{2} & 5 & 4 & 4 & 5 & 5 & 5 & 4 & 5 & 4 & 4 & 45 \\ \mathbf{3} & 5 & 5 & 5 & 5 & 5 & 5 & 5 & 5 & 5 & 4 & 49 \\ \mathbf{4} & 4 & 4 & 5 & 5 & 5 & 4 & 2 & 4 & 5 & 4 & 42 \\ \mathbf{5} & 5 & 5 & 5 & 4 & 5 & 5 & 5 & 5 & 5 & 5 & 49 \\ \mathbf{6} & 4 & 5 & 5 & 4 & 5 & 5 & 3 & 4 & 4 & 4 & 43 \\ \mathbf{7} & 4 & 4 & 5 & 4 & 4 & 4 & 5 & 4 & 5 & 5 & 44 \\ \mathbf{8} & 5 & 5 & 4 & 5 & 5 & 5 & 5 & 5 & 4 & 5 & 48 \\ \mathbf{9} & 5 & 5 & 5 & 5 & 5 & 5 & 5 & 5 & 5 & 5 & 50 \\ \mathbf{1 0} & 5 & 5 & 5 & 5 & 5 & 5 & 5 & 5 & 5 & 5 & 50 \\ \mathbf{1 1} & 4 & 5 & 5 & 5 & 4 & 5 & 5 & 5 & 5 & 5 & 48 \\ \mathbf{1 2} & 4 & 4 & 4 & 4 & 4 & 4 & 4 & 5 & 4 & 4 & 41 \\ \mathbf{1 3} & 4 & 3 & 4 & 4 & 5 & 5 & 4 & 5 & 5 & 5 & 44 \\ \mathbf{1 4} & 5 & 4 & 4 & 5 & 5 & 5 & 4 & 4 & 4 & 4 & 44 \\ \mathbf{1 5} & 5 & 4 & 4 & 5 & 4 & 4 & 5 & 5 & 4 & 5 & 45 \\ \mathbf{1 6} & 5 & 3 & 5 & 5 & 5 & 4 & 5 & 5 & 5 & 5 & 47 \\ \mathbf{1 7} & 5 & 5 & 5 & 5 & 5 & 5 & 5 & 5 & 5 & 5 & 50 \\ \mathbf{1 8} & 5 & 4 & 5 & 5 & 4 & 4 & 4 & 4 & 4 & 4 & 43 \\ \mathbf{1 9} & 5 & 5 & 4 & 5 & 4 & 5 & 5 & 5 & 4 & 5 & 47 \\ \mathbf{2 0} & 5 & 3 & 5 & 5 & 5 & 5 & 5 & 5 & 5 & 5 & 48 \\ \mathbf{2 1} & 5 & 4 & 4 & 5 & 5 & 5 & 4 & 4 & 4 & 4 & 44 \\ \mathbf{2 2} & 4 & 5 & 4 & 4 & 4 & 4 & 4 & 4 & 4 & 4 & 41 \\ \mathbf{2 3} & 4 & 4 & 4 & 5 & 4 & 4 & 5 & 4 & 5 & 4 & 43 \\ \mathbf{2 4} & 5 & 5 & 5 & 5 & 4 & 5 & 5 & 4 & 3 & 5 & 46 \\ \mathbf{2 5} & 5 & 4 & 3 & 5 & 5 & 5 & 5 & 5 & 5 & 5 & 47 \\ \mathbf{2 6} & 4 & 4 & 4 & 4 & 5 & 5 & 5 & 5 & 4 & 4 & 44 \\ \mathbf{2 7} & 5 & 3 & 4 & 5 & 5 & 5 & 5 & 5 & 5 & 5 & 47 \\ \mathbf{2 8} & 5 & 4 & 5 & 5 & 5 & 5 & 5 & 5 & 4 & 5 & 48 \\ \mathbf{2 9} & 5 & 4 & 5 & 5 & 4 & 4 & 4 & 5 & 4 & 4 & 44 \\ \mathbf{3 0} & 5 & 3 & 4 & 5 & 5 & 5 & 5 & 3 & 3 & 3 & 41 \\ \mathbf{3 1} & 5 & 4 & 5 & 5 & 4 & 5 & 5 & 5 & 5 & 5 & 48 \\ \mathbf{3 2} & 4 & 3 & 4 & 5 & 5 & 5 & 5 & 5 & 3 & 3 & 42 \\ \mathbf{3 3} & 5 & 5 & 5 & 5 & 5 & 5 & 5 & 5 & 5 & 5 & 50 \\ \mathbf{3 4} & 5 & 4 & 5 & 5 & 5 & 4 & 5 & 4 & 4 & 5 & 46 \\ \mathbf{3 5} & 4 & 4 & 4 & 5 & 5 & 5 & 5 & 4 & 5 & 5 & 46 \\ \mathbf{3 6} & 4 & 4 & 4 & 4 & 4 & 4 & 4 & 4 & 4 & 4 & 40 \\ & & & & & & & & & & & \end{array}$




$\begin{array}{llllllllllll}\mathbf{3 7} & 4 & 4 & 4 & 4 & 4 & 4 & 4 & 4 & 4 & 4 & 40 \\ \mathbf{3 8} & 4 & 4 & 5 & 5 & 4 & 4 & 5 & 4 & 5 & 5 & 45 \\ \mathbf{3 9} & 5 & 5 & 5 & 5 & 5 & 5 & 5 & 4 & 5 & 5 & 49 \\ \mathbf{4 0} & 4 & 3 & 4 & 4 & 4 & 4 & 4 & 4 & 4 & 4 & 39 \\ \mathbf{4 1} & 4 & 4 & 4 & 5 & 5 & 5 & 4 & 5 & 5 & 5 & 46 \\ \mathbf{4 2} & 5 & 5 & 5 & 5 & 5 & 5 & 5 & 5 & 5 & 5 & 50 \\ \mathbf{4 3} & 5 & 4 & 5 & 5 & 5 & 5 & 5 & 5 & 5 & 5 & 49 \\ \mathbf{4 4} & 4 & 4 & 5 & 4 & 4 & 4 & 5 & 5 & 5 & 5 & 45 \\ \mathbf{4 5} & 5 & 4 & 4 & 5 & 4 & 5 & 4 & 5 & 4 & 4 & 44 \\ \mathbf{4 6} & 5 & 4 & 4 & 5 & 5 & 5 & 4 & 4 & 4 & 4 & 44 \\ \mathbf{4 7} & 5 & 4 & 5 & 4 & 4 & 5 & 5 & 5 & 4 & 4 & 45 \\ \mathbf{4 8} & 5 & 5 & 5 & 5 & 5 & 5 & 5 & 5 & 5 & 5 & 50 \\ \mathbf{4 9} & 4 & 4 & 5 & 5 & 5 & 5 & 5 & 5 & 5 & 5 & 48 \\ \mathbf{5 0} & 5 & 4 & 4 & 5 & 5 & 5 & 4 & 3 & 4 & 4 & 43\end{array}$

3. Uji Validitas

Uji validitas digunakkan sebagai uji prasyarat untuk mengetahui apakah data yang akan dipakai untuk pengujian hipotesis merupakan data yang valid atau tidak. ${ }^{41}$ Untuk itu data yang telah didapat, harus diuji validitasnya terlebih dahulu.Dalam uji validitas ini, item pertanyaan yang dianggap valid adalah $r$ hitung $<r$ tabel. Berikut ini hasil uji validitas variabel kualitas pelayanan yalng telah dilakukan dengan menggunakan SPSS:

Tabel 4.6

Hasil Uji Validitas Kualitas Pelayanan

\begin{tabular}{ccccc} 
NO & Variabel X & \multicolumn{2}{c}{ Uji Validitas } & Keterangan \\
& Kualitas Pelayanan & r hitung & R table & \\
1 & Item 1 & 0,616 & 0,2787 & Valid \\
2 & Item 2 & 0,550 & 0,2787 & Valid \\
3 & Item 3 & 0,400 & 0,2787 & Valid \\
4 & Item 4 & 0,576 & 0,2787 & Valid
\end{tabular}

(Bandung: Alfabeta 2010),

hal.73. 
p-ISSN: 2654-3567

$\begin{array}{ccccc}5 & \text { Item 5 } & 0,616 & 0,2787 & \text { Valid } \\ 6 & \text { Item 6 } & 0,550 & 0,2787 & \text { Valid } \\ 7 & \text { Item 7 } & 0,463 & 0,2787 & \text { Valid } \\ 8 & \text { Item 8 } & 0,477 & 0,2787 & \text { Valid } \\ 9 & \text { Item 9 } & 0,576 & 0,2787 & \text { Valid } \\ 10 & \text { Item 10 } & 0,396 & 0,2787 & \text { Valid }\end{array}$

Sumber: Hasil Pengolahan Data, SPSS 20

Dari data di atas terdapat 10 item angket, setelah dihitung menggunakan SPSS diketahui semua item angket valid dan dapat digunakan untuk penelitian ini.

Berikut ini hasil uji validitas variabel Kepuasan Nasabah dalam Menggunakan Jasa LKMA Syariah Amanah Mandiri yang telah dilakukan dengan menggunakan SPSS:

Tabel 4.7

Hasil Uji Validitas Kepuasan Nasabah

\begin{tabular}{ccccc} 
NO & $\begin{array}{c}\text { Variabel Y } \\
\text { Angket Kepuasan } \\
\text { Nasabah }\end{array}$ & \multicolumn{2}{c}{ Uji Validitas } & Keterang \\
& r hitung & R table & \\
1 & Item 1 & 0,538 & 0,2787 & Valid \\
2 & Item 2 & 0,494 & 0,2787 & Valid \\
3 & Item 3 & 0,507 & 0,2787 & Valid \\
4 & Item 4 & 0,491 & 0,2787 & Valid \\
5 & Item 5 & 0,440 & 0,2787 & Valid \\
6 & Item 6 & 0,538 & 0,2787 & Valid \\
7 & Item 7 & 0,591 & 0,2787 & Valid \\
8 & Item 8 & 0,578 & 0,2787 & Valid \\
9 & Item 9 & 0,585 & 0,2787 & Valid \\
10 & Item 10 & 0,737 & 0,2787 & Valid
\end{tabular}

Dari data di atas terdapat 10 item angket, setelah dihitung menggunakan SPSS diketahui semua item angket valid dan dapat digunakan untuk penelitian ini. 


\section{Uji Reliabilitas}

Uji reliabilitas dalam penelitian ini juga dapat dilakukan dengan bantuan SPSS. Suatu variabel dapat dikatakan reliabel jika Crobanch"s Alpha dari variabel tersebut lebih besar dari 0,60 atau $60 \%{ }^{42}$ Berikut ini hasil uji reliabilitas variabel kualitas pelayanan yang telah dilakukan dengan menggunakan SPSS:

Table 4.8

\section{Hasil Uji Reliabilitas Variabel Kualitas Pelayanan \\ Reliability Statistics}

\begin{tabular}{|c|c|}
\hline Cronbach's Alpha & N of Items \\
\hline 0.706 & 10 \\
\hline
\end{tabular}

Sumber: Hasil Pengolahan Data, SPSS 17

Setelah diproses dengan SPSS, maka dapat diketahui bahwa Crobanch"s Alpha untuk variabel kualitas pelayanan adalah 0.706 atau 70,6 \%. Nilai Crobanch"s Alpha tersebut ternyata diatas 0,60 atau $60 \%$ maka dapat disimpulkan bahwa pertanyaan untuk variabel tersebut adalah reliabel untuk memiliki tingkat reliabilitas yang sangat baik.

Berikut ini hasil uji reliabilitas variabel kepuasan nasabah yang telah dilakukan dengan menggunakan SPSS:

\section{Tabel 4.9}

\section{Hasil Uji Reliabilitas Variabel Kepuasan Nasabah}

Reliability Statistics

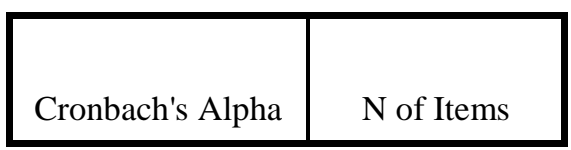

\footnotetext{
${ }^{42}$ Johar Arifin, spss 24 Untuk Peneliti Dan Skripsi,(Jakarta:Gramedia2011), hal. 56.
} 


\section{Reliability Statistics}

\begin{tabular}{|c|c|}
\hline Cronbach's Alpha & N of Items \\
\hline 0.743 & 10 \\
& \\
\hline
\end{tabular}

Sumber: Hasil Pengolahan Data, SPSS 17

Setelah diproses dengan SPSS, maka dapat diketahui bahwa Crobanch"s Alpha untuk variabel kualitas pelayanan adalah 0.743 atau 74,3\%. Nilai Crobanch"s Alpha tersebut ternyata diatas 0,60 atau $60 \%$ maka dapat disimpulkan bahwa pertanyaan untuk variabel tersebut adalah reliabel untuk memiliki tingkat reliabilitas yang sangat baik.

5. Persamaan Linier Sederhana

Untuk mempermudah perhitungan, maka dalam penelitian ini mempergunakan program SPSS 17 dengan alat analisis yang digunakan adalah analisis deskriptif.Analisis ini digunakan untuk mengukur pengaruh dan hubungan antar variabel independen terhadap variabel dependen.

Tabel 4.10

\section{Hasil Regresi Sederhana}

Coefficients $^{\mathrm{a}}$

\begin{tabular}{|c|c|c|c|c|c|}
\hline \multirow{2}{*}{ Model } & \multicolumn{2}{|c|}{$\begin{array}{c}\text { Unstandardized } \\
\text { Coefficients }\end{array}$} & $\begin{array}{c}\text { Standardized } \\
\text { Coefficients }\end{array}$ & & \\
\cline { 2 - 5 } & $\mathrm{B}$ & Std. Error & Beta & $\mathrm{T}$ & Sig. \\
\hline 1 (Constant) & 26.662 & 5.622 & & 4.742 & .000 \\
$\begin{array}{c}\text { kualitas } \\
\text { pelayanan }\end{array}$ & .436 & .129 & .437 & 3.366 & .002 \\
\hline
\end{tabular}

a. Dependent Variable: kepuasan nasabah

Sumber: Hasil Pengolahan Data, SPSS 17 
Berdasarkan hasil regresi sederhana pada tabel 4.10, maka diperoleh persamaan regresi sebagai berikut:

$\mathrm{Y}=\mathrm{a}+\mathrm{bX}$

Kemudian hasil estimasi pada tabel akan dimasukkan ke dalam model penelitian. Maka dapat ditulis dalam persamaan di bawah ini:

$\mathrm{Y}=26.662+0.436 \mathrm{X}$

Keterangan:

* Signifikan pada $\propto=5 \%(0,05)$

Berdasarkan hasil analisis regresi sederhana, Persamaan diatas dapat diartikan sebagai berikut:

1. Nilai konstanta sebesar 26.662 menyatakan bahwa jika variabel independen yaitu Kualitas Pelayanan (X = 0), maka akan menaikkan Kepuasan Nasabah sebesar 26.662 persen.

2. Kualiltas Pelayanan berpengaruh positif dan signifikan dengan nilai koefesien sebesar 0.436 artinya apabila terjadi kenaikan kualitas pelayanan sebesar 1 satuan, maka akan menaikan kepuasan nasabah 0.436 .

6. Uji Analisis Koefisien Korelasi (R)

Uji analisis koefisien korelasi menunjukan kemampuan hubungan antara variabel bebas dengan variabel terikat. ${ }^{43}$ Angka koefisien yang dihasilkan dalam uji ini berguna untuk menunjukan kuat lemahnya hubungan antara variabel independen dengan variabel dependen.

Tabel 4.11

Koefisien Korelasi (R)

Model Summary

\begin{tabular}{|c|c|c|c|c|}
\hline Model & $\mathrm{R}$ & R Square & $\begin{array}{c}\text { Adjusted R } \\
\text { Square }\end{array}$ & $\begin{array}{c}\text { Std. Error of the } \\
\text { Estimate }\end{array}$ \\
\hline 1 & $.437^{\mathrm{a}}$ & .191 & .174 & 2.75535 \\
\hline
\end{tabular}

a. Predictors: (Constant), kualitas pelayanan

${ }^{43}$ Dr.suharsimi Arikunto, Prosedur Penelitian, (Rineka Cipta, Jakarta,2013), hal. 43. 
Sumber: Hasil Pengolahan Data, SPSS 1

Penaksiran besarnya korelasi yang digunakan adalah:

Interval Koefisien
$0.00-0.199$
$0.20-0.399$
$0.40-0.599$
$0.60-0.799$
$0.80-1.000$
Sangat Rendah
Rendah
Sedang
Kuat
Sangat Kuat

Tingkat Hubungan

Sumber: Hasil Pengolahan Data, SPSS 17

Berdasarkan tabel diatas diperoleh koefisien korelasi sebesar 0.437 terletak pada interval koefisien $0.40-0.599$ yang berarti tingkat hubungannya cukup atau sedang.

7. Uji Koefisien Determinasi $\left(R^{2}\right)$

Koefesien Determinasi $\left(R^{2}\right)$ bertujuan untuk mengetahui seberapa jauh variasi variabel independen dapat menerangkan dengan baik variasi variabel dependen.

Tabel 4.12

Determinasi (R2)

Model Summary

\begin{tabular}{|c|c|c|c|c|}
\hline Model & $\mathrm{R}$ & R Square & $\begin{array}{c}\text { Adjusted R } \\
\text { Square }\end{array}$ & $\begin{array}{c}\text { Std. Error of } \\
\text { the Estimate }\end{array}$ \\
\hline 1 & $.437^{\mathrm{a}}$ & .191 & .174 & 2.75535 \\
\hline
\end{tabular}

a. Predictors: (Constant), kualitas pelayanan

Sumber: Hasil Pengolahan Data, SPSS 17

Dari hasil perhitungan bahwa koefisien determinasi (R2) sebesar 0.191 ini berarti variasi variabel terikat kepuasan nasabah sebesar 
19,1\% dipengaruhi oleh perubahan kualitas pelayanan, sedangkan 80,9\% dipengaruhi oleh faktor-faktor lain seperti kebutuhan yang mendesak, dan yang lainnya.

\section{Uji Hipotesis}

Pengujian statistik dilakukan untuk mengetahui ada tidaknya pengaruh variabel Kualitas Pelayanan terhadap kepuasan nasabah. Hipotesis pengujian t- statistik secara rinci dapat di uraikan sebagai berikut:

Ho: $\beta 1=0$ : artinya variabel Kualitas Pelayanan tidak berpengaruh terhadap kepuasan nasabah.

Ha : $\beta 1 \neq 0$ : artinya variabel Kualitas Pelayanan berpengaruh terhadapkepuasan nasabah.

Pengambilan keputusan menggunakan a yang ditetapkan yaitu ( 5 persen $=0,05)$, maka jika probabilitasnya $>$ a, maka Ho diterima, sedangkan jika probabilitasnya $<\mathrm{a}$, maka Haditerima. Berikut ini adalah hasil pengujian t-statistik yang disajikan dalam tabel 4.11 sebagai berikut:

\section{Tabel 4.13}

Uji t-statistik Coefficients ${ }^{\text {a }}$

\begin{tabular}{|c|c|c|c|c|c|}
\hline \multirow[b]{2}{*}{ Model } & \multicolumn{2}{|c|}{$\begin{array}{c}\text { Unstandardized } \\
\text { Coefficients }\end{array}$} & \multirow{2}{*}{$\begin{array}{c}\begin{array}{c}\text { Standardized } \\
\text { Coefficients }\end{array} \\
\text { Beta }\end{array}$} & \multirow[b]{2}{*}{$\mathrm{T}$} & \multirow[b]{2}{*}{ Sig. } \\
\hline & B & Std. Error & & & \\
\hline 1(Constant) & 26.662 & 5.622 & & 4.742 & .000 \\
\hline $\begin{array}{l}\text { kualitas } \\
\text { pelayanan }\end{array}$ & .436 & .129 & .437 & 3.366 & .002 \\
\hline
\end{tabular}

a. Dependent Variable: kepuasan nasabah

Sumber: Hasil Pengolahan Data, SPSS 17

Berdasarkan hasil pengujian t-statistik pada tabel 4.13 di atas, menunjukkan bahwa adanya pengaruh yang signifikan dari variabel independen, yaitu kualitas pelayanan. Berikut adalah penjelasan dari hasil uji t-statistik pada variabel independen: 
Variabel kualitas pelayanan memiliki nilai t-statistik sebesar 4.742 yang nilainya lebih besar dari t-tabel sebesar 2.011 sehingga hipotesis Ho ditolak dan Ha diterima, dapat disimpulkan bahwa variabel kualitas pelayanan berpengaruh signifikan terhadap kepuasan nasabah.

Berdasarkan hasil pengujian hipotesis statistik tersebut menunjukkan bahwa variabel bebas dalam model penelitian yaitu kualits pelayanan memiliki pengaruh signifikan terhadap kepuasan nasabah sebagai variabel terikat. 